\title{
Heavy metal characterization of waste portable rechargeable batteries used in mobile phones
}

\author{
${ }^{1 *}$ I. C. Nnorom; ${ }^{2}$ O. Osibanjo \\ ${ }^{1}$ Department of Industrial Chemistry, Abia State University, Abia State, Nigeria \\ ${ }^{2}$ Department of Chemistry, University of Ibadan, Nigeria
}

Received 4 October 2008; $\quad$ revised 17 July 2009; $\quad$ accepted 16 August 2009; $\quad$ available online 1 September 2009

\begin{abstract}
Ten brands of spent portable rechargeable batteries used in mobile phones (lithium-ion and nickel metal hydride) were collected and disassembled and the battery electrode and printed wiring board prepared using the EPA Method 3050B. The metal concentrations were determined by atomic absorption spectrometry. The mean ( \pm standard deviation) concentrations and range of cobalt, chromium, nickel and cadmium in the battery electrodes were $361284 \pm 32281 \mathrm{mg} / \mathrm{kg}$ (range 20870-575330 mg/kg); $25.3 \pm 4.6 \mathrm{mg} / \mathrm{kg}$ (7.9-149 mg/kg); $75272 \pm 14630 \mathrm{mg} / \mathrm{kg}$ (3589$266607 \mathrm{mg} / \mathrm{kg}$ ) and $2.8 \pm 0.6 \mathrm{mg} / \mathrm{kg}(0.2-16.3 \mathrm{mg} / \mathrm{kg})$, respectively. Similarly, the mean values of cobalt, chromium, nickel and cadmium in the PWB were $564 \pm 165 \mathrm{mg} / \mathrm{kg}(56.1-4068 \mathrm{mg} / \mathrm{kg}) ; 28.1 \pm 4.0 \mathrm{mg} / \mathrm{kg}$ (ND-97.2 mg/kg); $735 \pm$ $188 \mathrm{mg} / \mathrm{kg}(22.7-2727 \mathrm{mg} / \mathrm{kg}$ ) and $1.8 \pm 0.3 \mathrm{mg} / \mathrm{kg}$ (ND-7.2 mg/kg), respectively. The Li-ion battery electrodes contained significantly higher levels of cobalt $(\mathrm{p}<0.01)$ whereas, the NiMH battery contained significantly higher nickel $(\mathrm{P}<$ 0.01 ). All the results for the cobalt and nickel levels in the battery electrodes exceeded the toxicity threshold limit concentration used in the toxicity characterization of solid wastes (cobalt, $8000 \mathrm{mg} / \mathrm{kg}$; nickel , $2000 \mathrm{mg} / \mathrm{kg}$ ). In fact, the mean cobalt level of the battery electrode is about 45 times the toxicity threshold limit concentration limit for cobalt while the mean nickel result is about 38 times the toxicity threshold limit concentration. Spent portable rechargeable batteries should be handled as toxic materials that require special treatment. Implementation of a well-coordinated management strategy for spent batteries is urgently required to check the dissipation of large doses of toxic heavy metals and rare earth into the environment.
\end{abstract}

Keywords: Environmental pollution; Lithium ion; Nickel metal hydride; Toxicity characterization; Waste battery

\section{INTRODUCTION}

The management of spent primary and secondary batteries has been an issue of environmental concern in developing countries especially considering the absence of basic waste collection and management infrastructure (Zabaniotou et al., 1999; Aktas et al., 2004; Nnorom and Osibanjo, 2006a; Abdel-Ghani et al., 2007; Daryabeigi Zand and Abduli, 2008; Rabah et al., 2008). Batteries represent a large volume of toxic and hazardous materials in common use (Lankey and McMicheal, 1999). Waste management in general has emerged as a major problem for urban cities (Aina et al., 2009). Adopting inappropriate mean in the management of wastes could result in environmental pollution (Giri et al., 2007; Ogundiran and Afolabi, 2008).

Batteries contain a wide variety of materials such as carbon, steel, plastic, heavy metals and salts (electrolytes). While materials such as carbon are not

*Corresponding Author Email: chidiabsu@yahoo.co.uk Tel: +234 8053 347786, Fax: +234 28103168 so aggressive to the environment and can quickly merge into the eco-system without noticeable impacts, others such as heavy metals pose threat to the ecosystem and man (Nnorom and Osibanjo, 2006b; Osibanjo et al., 2008). The fate of spent rechargeable batteries is an important and timely issue, primarily because of the toxic and hazardous materials they contain. The consumption of portable rechargeable batteries in Nigeria has been phenomenal since the introduction of mobile telecommunication in the country in 2000. For instance, in 1999, about 179,295 $\mathrm{kg}$ of portable rechargeable batteries were imported into Nigeria. Consumption of portable rechargeable batteries has also increased with increase in subscription of mobile telecommunication from a mere 30,000 subscribers in 1999 to more than 40 million subscribers in 2007. As at April 2009, the teledensity in Nigeria was 47.98 with 67 million active lines and an installed capacity of 133million lines. 
The NiMH and Li-ion batteries do not contain cadmium, which is highly toxic and are therefore considered environmentally acceptable. This and the better performance offered by these batteries led to the replacement of NiCd in many application by the NiMH and Li-ion batteries. These new types of battery make-up about 10- 30 \% portable sources of energy depending on the region (Gega and Walkowiak, 2001). In 2002, out of the total rechargeable batteries available in the market for use in mobile phones and communication devices $66 \%$ is Li-based batteries while the rest used nickel-based batteries (Arora and Zhang, 2004). The NiMH batteries are not only Cd-free, but also can store more energy than their NiCd of comparable size (Rydh and Svard, 2003). However, $\mathrm{NiMH}$ batteries are not as environmental friendly as presented as they contain toxic materials such as $\mathrm{Ni}$, a toxic and carcinogenic material (Lankey and McMicheal, 1999). Also the Li-ion and NiMH batteries contain metals (such as La, Nd and Co) for which only a few have their toxicological or ecotoxicological data available. As a result, Rydh and Svard (2003) opined that the production and consumption of batteries containing these 'new' metals is associated with uncertainties regarding their environmental impact and could result in a change from one problematic metal to another. Meanwhile, the potential environmental impact of spent batteries depends on the disposal options adopted.

The use of portable rechargeable batteries represents a true 'source reduction' since this reduces the amount of batteries consumed and the volume of waste spent batteries generated over time. This is the case considering that majority of these portable rechargeable batteries can be recharged and reused as many as one thousand times ( $\mathrm{Lu}$ and Chung, 2003). They have better performance characteristics (such as high energy density) which are desired in many applications (Moshtev and Johnson, 2000). NiMH and Li-ion batteries are special purpose rechargeable batteries used in computers, cell phones, video cameras, ipods and PDAs. Li-ion battery is the fastest growing battery technology today (Saito et al., 2003; Castillo et al., 2004; Lupi et al., 2005). It has significant high energy density and twice the life cycle of a NiMH battery. Nevertheless, they can be more expensive than NiMH batteries and unsafe when improperly used or disposed (Lankey and McMicheal, 1999; Castillo et al., 2004).

At the global level, battery manufacturers produced 1.4 billion NiCd batteries, 1 billion NiMH batteries and about 0.41 billion Li-based batteries in 1999 (Rydh and Svard, 2003). The world market for batteries was approximately $\$ 41$ billion in 2000, which included $\$ 16.2$ billion for primary and \$ 24.9 billion for secondary batteries. The rechargeable battery (NiCd, NiMH, Liion) market for 2003 for portable electronics was around $\$ 5.24$ billion, around $20 \%$ more than 2002 (Arora and Zhang, 2004).

In Nigeria, portable nickel metal hydride batteries and Lithium ion batteries are used mainly in mobile telephones. This paper reports the result of a study aimed to characterizing waste $\mathrm{NiMH}$ and Li-ion rechargeable batteries used in mobile phones. The objective of this research was to assess the level of selected metals ( $\mathrm{Co}, \mathrm{Cr}, \mathrm{Cd}$, and $\mathrm{Ni}$ ) in waste portable rechargeable batteries as pollution indicator of spent batteries. This has become necessary in the light of the phenomenal increase in the consumption of these batteries in Nigeria and the inappropriate methods used in the management of end-of-life $(\mathrm{EoL})$ rechargeable batteries and other waste electronic devices. Such waste materials are routinely burned openly or disposed of into surface waters or with municipal solid waste. This study was carried out in early 2007 in Abia State University, Southeastern Nigeria.

\section{MATERIALS AND METHODS}

\section{Sample collection}

A total of eighty-five spent batteries were collected from mobile phone users, mobile phone repairers/ technicians and retailers of mobile phone accessories in Isuikwuato, Aba and Okigwe all in Southeastern Nigeria. Batteries collected were of two different battery chemistries - the NiMH and the Li-ion battery systems. The batteries were grouped according to battery system, voltage capacity, model, manufacturer and country of origin. Batteries with any form of clear physical defect were rejected. These criteria were used in selecting representative samples for analysis. In the end, thirty-one samples were selected; 22 Li-ion batteries and 9 NiMH batteries. These samples are true representatives of both the batteries being imported in large quantities into the country and the batteries at their end-of-life and currently being managed in the country. Ten different brands were studied: Bird, Motorola, Sony Erickson, Flying Horse, Samsung, SkyHawk, Sagem, Alcatel and Nokia. The batteries studied were manufactured in the United Kingdom, China, Japan, Hungary, Korea and Taiwan. Most of the batteries were produced between 2000-2006. Up to five samples were included for some brands whereas for 
brands that are not regularly in use in the country, tne only available samples were used.

\section{Sample preparation}

The batteries were disassembled using stainless steel screwdrivers, hammer and pliers and then separated into the major components- plastic/metal housing, electrode, separators and printed wiring board, (PWB). The electrode components were unwound and size-reduced, using stainless scissors. Some of the PWB samples were also size-reduced using giant stainless steel scissors. The PWB samples of all battery samples were analyzed except for two samples of a particular brand. The samples (electrode and PWB) were then sealed in polyethylene bags, labeled and stored prior to the next analytical procedure.

\section{Sample analysis}

The California Department for Toxic Substance Control (DTSC) established the toxicity threshold limit concentration (TTLC) for the toxicity characterization of solid wastes. The TTLC procedure requires the use of the EPA Method 3050B in sample analysis with the aim of determining the total soluble constituents of the materials (DTSC, 2004a, b). The total metal concentration of a solid waste could give an indication of the percentage of metals that could become bioavailable in the soil. As a result, the US EPA Method 3050B determines the amount of metals that becomes available under the worst-case environmental condition (EPA, 1996; Townsend et al., 2001). The metal (or constituent) levels obtained are then compared with the TTLC threshold limits. This is applied in decision making with respect to adopting management practices for waste materials and is used in the classification of materials as toxic and hazardous. A known weight (1g sample, except in some PWB samples) of the battery electrode and PWB was prepared using the procedures of the EPA Method 3050B. The EPA Method 3050B requires the preparation of the samples using nitric acid, hydrochloric acid and hydrogen peroxide (30 \%). Details of the method have been reported elsewhere and have been variously used in the characterization of electronic waste devices (DTSC, 2004a, b; Li et al., 2006; Lincoln et al., 2007). The sample digests were subsequently analyzed for $\mathrm{Cr}$, Co, Cd, and Ni by atomic absorption spectroscopy (UNICAM SOLAAR 32).

\section{Quality control}

Quality assurance/quality control measures (duplicate anaıysıs, metal spikes and blanks) were carried out to ensure reliability of results. All glass and plastic ware were cleaned prior to use by soaking in $5 \%$ nitric acid overnight, rinsing with water and storing clean. All reagents $\left(\mathrm{H}_{2} \mathrm{SO}_{4}, \mathrm{HNO}_{3} \mathrm{H}_{2} \mathrm{O}_{2}\right.$ and deionized water) were of analytical grade. Blanks were introduced with $20 \%$ insertion rate. Chemical analysis of materials such as these present challenges due to the physical nature of the devices (size and composition changes) and the potential heterogeneity within devices and between devices (DTSC, 2004a; Nnorom and Osibanjo, 2008). Between sample and within sample replicate studies were carried out in order to check the heterogeneity in the electrodes of selected individual samples and variations of metal contents of samples of the same brand (and battery chemistry).

\section{RESULTS AND DISCUSSION}

Summary of metal concentrations in sample

The brands of different portable rechargeable batteries were labeled A-L in order not to disclose their identity. The results of the concentrations of heavy metals in the electrode and PWB of the batteries according to brand and battery chemistry (NiMH or Li-ion) are presented in Tables 1 and 2 respectively. A summary of the result and the comparison with the TTLC threshold limits for the various metals are presented in Table 3 and Table 4 for battery electrode and PWB respectively.

The precision of the replicate analysis for testing within sample heterogeneity expressed as the coefficient of variation is: $22 \%$ for Co; $41 \%$ for Cd; $19 \%$ for $\mathrm{Cr}$ and $51 \%$ for $\mathrm{Ni}$. The precision of the replicate analysis for testing between-sample heterogeneity expressed as the coefficient of variation varied from $0.8 \%$ to $19 \%$ for Co and from $4 \%$ to $42 \%$ for Cr. The variation in the result of the replicate analysis as reflected in the high values of some of the calculated precision may have resulted from unequal distribution of the metals in the battery electrodes and also from the variations from batch-to-batch inconsistencies and differences in brand manufacturing practices. Results of replicate analysis of metals in electronic devices reported a precision (expressed as coefficient of variation) of $27 \%$ for $\mathrm{Cd}$, $33 \%$ for $\mathrm{Pb}, 67 \%$ for $\mathrm{Ni}$ and $11 \%$ for Ag (DTSC, 2004b). The overall mean ( \pm standard error of mean, SEM) concentrations of $\mathrm{Co}, \mathrm{Cr}, \mathrm{Ni}$ and $\mathrm{Cd}$ in the battery electrodes are $361284 \pm 32281 \mathrm{mg} / \mathrm{kg} ; 25.3 \pm 4.6 \mathrm{mg} / \mathrm{kg}$; $75272 \pm 14630 \mathrm{mg} / \mathrm{kg}$; and $2.8 \pm 0.6 \mathrm{mg} / \mathrm{kg}$, respectively. 
Similarly, the mean ( \pm SEM) of $\mathrm{Co}, \mathrm{Cr}$, $\mathrm{Ni}$ and $\mathrm{Cd}$ in the PWB are $564 \pm 165 ; 28.1 \pm 4.0 ; 735 \pm 188$ and $1.8 \pm 0.3$ respectively. In most cases, the standard deviation values were higher than the mean values. The very high standard deviation of most of the results indicates the heterogeneous nature of the samples as a result of the factors outlined above (as seen in the very high coefficient of variation values). This is also observed in the very wide range of the results (Table 1 and Table 2). The metal concentrations in the battery electrodes (for the Li-ion and NiMH battery chemistries) follow the order: $\mathrm{Co}>\mathrm{Ni}>\mathrm{Cr}>\mathrm{Cd}$.

\section{Metal levels in battery electrode}

A summary of the analytical results of the total metal concentrations in the electrodes of mobile phone rechargeable battery systems according to brand is presented in Table 1 . The mean values obtained ranged from $93730 \pm 24800 \mathrm{mg} / \mathrm{kg}$ for brand D (NiMH) to 492640 $\pm 350419 \mathrm{mg} / \mathrm{kg}$ for B(Li-ion) for cobalt; from $12.7 \pm 0.4$ $\mathrm{mg} / \mathrm{kg}$ for B (Li-ion) to $51.9 \pm 24.3 \mathrm{mg} / \mathrm{kg}$ for $\mathrm{G}$ (Li-ion) for chromium and from $9104 \pm 5514 \mathrm{mg} / \mathrm{kg}$ for B (Li-ion) to $138787 \pm 71028 \mathrm{mg} / \mathrm{kg}$ for $\mathrm{C}$ (Li-ion) for nickel. The mean cadmium levels were generally less than $7 \mathrm{mg} / \mathrm{kg}$. The summary of the results obtained is presented in Table 3. The result of the metal concentrations of battery electrodes of the Li-ion and NiMH batteries were compared with data from literature (Table 5). The comparison indicated significant closeness between the results of this study and data from literature. The slight variation in some of the metals especially Co and $\mathrm{Ni}$ may be attributed to the observation that the data from literature (Rydh and Svard, 2003) were weighted averages of the entire battery, including plastics and packaging materials. Other factors that may contribute to this variation apart from the normal statistical variations are variations due to differences in brand manufacturing standards/specifications, differences in battery chemistries, battery capacity (voltage deliverable) and batch-to-batch inconsistencies among others.

\section{Metal levels in battery PWB}

The results of the total metal concentrations in the printed wiring boards of battery systems according to brand are presented in Table 2. The mean cadmium

Table 1: Result of metal levels of electrodes of rechargeable batteries according to brand (mg/kg)

\begin{tabular}{|c|c|c|c|c|}
\hline Brand & Co & $\mathrm{Cr}$ & $\mathrm{Cd}$ & $\mathrm{Ni}$ \\
\hline A* Mean \pm SD & $276104 \pm 115990$ & $20.5 \pm 6.1$ & $7.0 \pm 4.7$ & $127335 \pm 73987$ \\
\hline Range & 44199-396847 & $11.7-32.3$ & $1.7-16.3$ & $14400-266607$ \\
\hline \multirow[t]{2}{*}{ B } & $492640 \pm 350419$ & $12.7 \pm 0.4$ & $\mathrm{Na}$ & $9104 \pm 5514$ \\
\hline & 489714-495567 & $12.3-13.0$ & ND-0.2 & $3589-14617$ \\
\hline \multirow[t]{2}{*}{$\mathrm{C}$} & $414439 \pm 7144$ & $18.4 \pm 2.1$ & $3.62 \pm 0.8$ & $138787 \pm 71028$ \\
\hline & 273213-503842 & $14.6-22.0$ & $2.4-5.1$ & $4446-245947$ \\
\hline \multirow[t]{2}{*}{$\mathrm{D}^{*}$} & $93730 \pm 24800$ & $26.4 \pm 14.3$ & $3.1 \pm 0.1$ & $122758 \pm 66653$ \\
\hline & 61776-142561 & $7.9-54.5$ & 2.99-3.15 & $6097-236953$ \\
\hline \multirow[t]{2}{*}{ E } & $477042 \pm 50548$ & $27.6 \pm 6.7$ & $3.6 \pm 1.8$ & $52200 \pm 28010$ \\
\hline & 38349-548238 & $17.8-46.7$ & ND-7.9 & $5246-117723$ \\
\hline \multirow[t]{2}{*}{ F } & $443008 \pm 42772$ & $21.4 \pm 0.7$ & $2.7 \pm 0.6$ & $44647 \pm 34933$ \\
\hline & 348782-554936 & 20.2-23.3 & ND-3.4 & $4710-149291$ \\
\hline \multirow[t]{2}{*}{ G } & $402350 \pm 94272$ & $51.9 \pm 24.3$ & $1.2 \pm 0.3$ & $89163 \pm 38781$ \\
\hline & 38349-548238 & 27.1-149 & 0.8-1.9 & 4484-221189 \\
\hline \multirow[t]{2}{*}{$\mathrm{H}^{*}$} & $463888 \pm 17782$ & $17.3 \pm 3.6$ & $1.5 \pm 0.1$ & $54798 \pm 9276$ \\
\hline & 446106-481671 & $13.7-20.8$ & $1.4-1.7$ & $42130-45522$ \\
\hline \multirow[t]{2}{*}{ I } & $208258 \pm 187388$ & $14.0 \pm 0.3$ & na & $61044 \pm 18914$ \\
\hline & 20870-395646 & $13.8-14.3$ & ND & 42130-79958 \\
\hline $\mathrm{J}^{*}$ & 314225 & 10.9 & 2.2 & 4541 \\
\hline $\mathrm{K}$ & 40934 & 10.4 & 10.3 & 6181 \\
\hline $\mathrm{L}$ & 470306 & 33.5 & 2.8 & 76974 \\
\hline
\end{tabular}

*NiMH battery system, others are Li-ion system;

na = not applicable; $\mathrm{ND}=$ not detectable 
Int. J. Environ. Sci. Tech., 6 (4), 641-650, Autumn 2009

Table 2: Heavy metal concentrations of PWB of rechargeable batteries according to brand (mg/kg)

\begin{tabular}{|c|c|c|c|c|}
\hline Brand & $\mathrm{C}$ & $\mathrm{Cr}$ & $\mathrm{Cd}$ & $\mathrm{Ni}$ \\
\hline A* Mean \pm SD & $276104 \pm 115990$ & $20.5 \pm 6.1$ & $7.0 \pm 4.7$ & $127335 \pm 73987$ \\
\hline Range & 44199-396847 & $11.7-32.3$ & $1.7-16.3$ & $14400-266607$ \\
\hline B & 489714-495567 & $12.3-13.0$ & ND-0.2 & $3589-14617$ \\
\hline $\mathrm{C}$ & $414439 \pm 7144$ & $18.4 \pm 2.1$ & $3.62 \pm 0.8$ & $138787 \pm 71028$ \\
\hline $\mathrm{D}^{*}$ & $61776-142561$ & $7.9-54.5$ & 2.99-3.15 & $6097-236953$ \\
\hline \multirow[t]{2}{*}{$\mathrm{E}$} & $477042 \pm 50548$ & $27.6 \pm 6.7$ & $3.6 \pm 1.8$ & $52200 \pm 28010$ \\
\hline & $38349-548238$ & $17.8-46.7$ & ND-7.9 & $5246-117723$ \\
\hline $\mathrm{F}$ & $443008 \pm 42772$ & $21.4 \pm 0.7$ & $2.7 \pm 0.6$ & $44647 \pm 34933$ \\
\hline \multirow[t]{2}{*}{$\mathrm{H}^{*}$} & $463888 \pm 17782$ & $17.3 \pm 3.6$ & $1.5 \pm 0.1$ & $54798 \pm 9276$ \\
\hline & $446106-481671$ & $13.7-20.8$ & $1.4-1.7$ & $42130-45522$ \\
\hline \multirow[t]{2}{*}{ I } & $208258 \pm 187388$ & $14.0 \pm 0.3$ & na & $61044 \pm 18914$ \\
\hline & 20870-395646 & $13.8-14.3$ & ND & $42130-79958$ \\
\hline $\mathrm{J}^{*}$ & 314225 & 10.9 & 2.2 & 4541 \\
\hline K & 40934 & 10.4 & 10.3 & 6181 \\
\hline $\mathrm{L}$ & 470306 & 33.5 & 2.8 & 76974 \\
\hline
\end{tabular}

*NiMH battery system, others are Li-ion system;

na $=$ not applicable; $\mathrm{ND}=$ not detectable

Table 3: Summary of heavy metal levels in rechargeable battery electrode $(\mathrm{mg} / \mathrm{kg})$

\begin{tabular}{|c|c|c|c|c|c|}
\hline Metal & Mean \pm SD & TTLC (Limit) & $\mathrm{N}>$ TTLC & GM & Range \\
\hline Co & $361284 \pm 32281$ & 8000 & 31 & 272077 & $20870-575330$ \\
\hline $\mathrm{Cr}$ & $25.3 \pm 4.6$ & 2500 & 0 & 20.8 & 7.9-149 \\
\hline $\mathrm{Ni}$ & $75272 \pm 14630$ & 2000 & 31 & 32572 & 3589-266607 \\
\hline $\mathrm{Cd}$ & $2.8 \pm 0.6$ & 100 & 0 & 1.7 & $0.2-16.3$ \\
\hline
\end{tabular}

$\mathrm{N}>\mathrm{TTLC}=$ Number of samples greater than the respective TTLC threshold $\mathrm{GM}=$ Geometric mean

results were generally less than $5 \mathrm{mg} / \mathrm{kg}$ (ND-4.6 for brand $\mathrm{E})$. The mean cobalt results range from $139 \pm$ $35.8 \mathrm{mg} / \mathrm{kg}$ for B (Li-ion) to $1340 \pm 1332 \mathrm{mg} / \mathrm{kg}$ for F. Similarly, the chromium and nickel results range from $13.8 \pm 17.9 \mathrm{mg} / \mathrm{kg}$ for $\mathrm{G}$ to $46.8 \pm 26.0 \mathrm{mg} / \mathrm{kg}$ for $\mathrm{F}$ and from $177 \pm 117 \mathrm{mg} / \mathrm{kg}$ for $\mathrm{G}$ (Li-ion) to $2482 \pm 347 \mathrm{mg} / \mathrm{kg}$ for I (Li-ion), respectively. The summary of the results obtained is presented in Table 4.

\section{Distribution of results}

Fig. 1 (a-c) depict the distribution of the results of concentrations of $\mathrm{Co}, \mathrm{Ni}$ and $\mathrm{Cr}$ for the battery electrodes respectively. The histograms are bimodal in nature, though positively skewed in the case of Co results and negatively skewed for the plots of the $\mathrm{Ni}$ and $\mathrm{Cr}$ results. Fig. 1a, indicates that a greater percentage of the samples contained more than 400,000 $\mathrm{mg} / \mathrm{kg}$ of Co in their electrodes. Analysis of the data obtained showed that approximately $77 \%$ of the battery samples studied contained greater than $300,000 \mathrm{mg} / \mathrm{kg}$ cobalt in their electrode. Meanwhile, about $45 \%$ of the samples contained about $30000 \mathrm{mg} /$ $\mathrm{kg} \mathrm{Ni}$ in the electrode with about $55 \%$ of the samples containing greater than $60000 \mathrm{mg} / \mathrm{kg}$ nickel (Fig. 1b). Similarly, about $80.5 \%$ of the samples contained $\mathrm{Cr}$ within the range $10-30 \mathrm{mg} / \mathrm{kg}$. The $\mathrm{Cr}$ result appears better distributed (Fig. 1c).

Comparison of metal levels in NiMH and Li-ion batteries

Comparison of the results of metal levels in the electrodes of NiMH and Li-ion battery systems was 


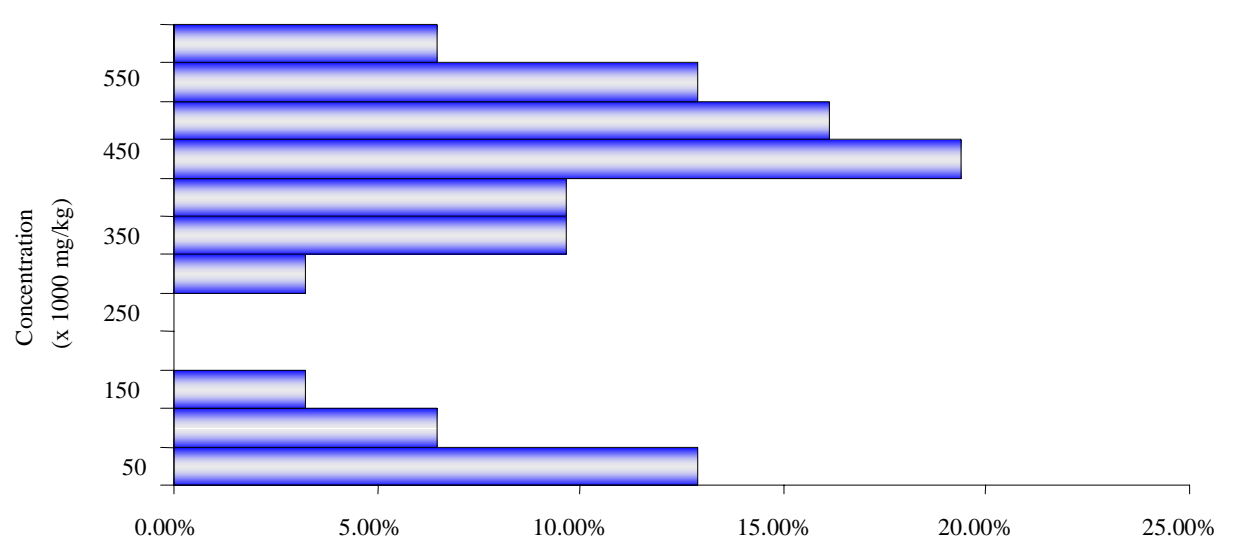

Fig. 1(a): Distribution of the Co results for battery electrodes

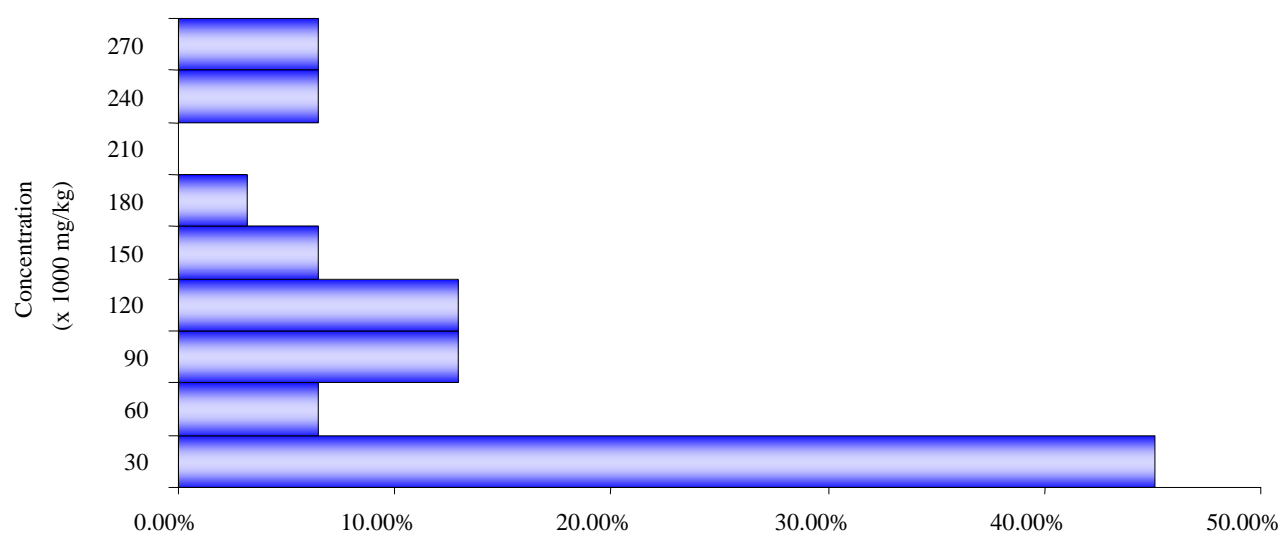

Fig. 1(b): Distribution of the Ni results for battery electrodes

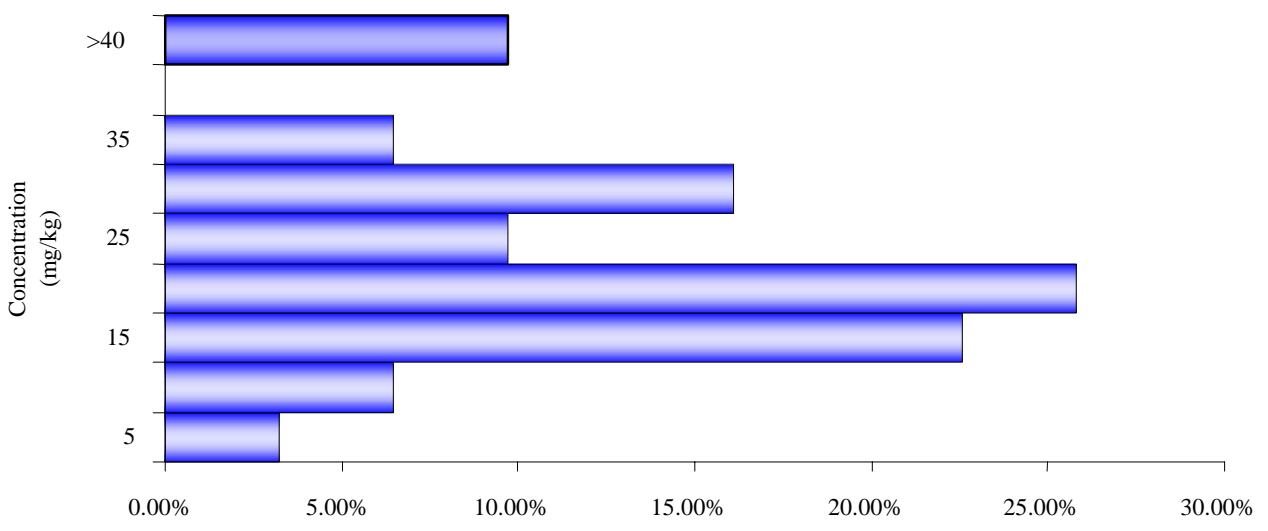

Fig. 1(c): Distribution of the Cr results for battery electrodes 
carried out by comparing the metal levels in four batteries (two each of NiMH and Li-ion chemistries) manufactured by two different companies. This indicated that the Co content of the electrodes of $\mathrm{Li}$ ion cells were higher by about 7 times, as compared to the NiMH batteries of the same brand (data not presented). The Ni levels of the NiMH batteries were higher than the corresponding values for Li-ion by as much as 50 times. Therefore, it indicates that Li-ion battery contains more Co than the NiMH systems. A look at the entire results grouped according to battery system (NiMH and Li-ion) indicated that the mean Co concentration of the Li-ion batteries is approximately 2-times the mean concentration of the NiMH type (Table 6). Conversely, the NiMH batteries contain more Ni. Difference of mean values of the Li-ion and NiMH tested by t-test are statistically significant at the level of $\mathrm{p}<0.01$ for Co and $\mathrm{p}<0.05$ for Ni. The test of mean indicated that the Li-ion batteries contain significantly higher levels of $\mathrm{Co}(\mathrm{p}<0.01)$ than the NiMH cells while the NiMH cells contain higher levels of $\mathrm{Ni}(\mathrm{p}<0.05)$ than the Li-ion batteries.

\section{Comparison with established regulatory thresholds}

Comparison of the results of this study with the TTLC threshold limits are presented in Tables 3 and 4 for battery electrode and PWB, respectively. The results indicated very high levels of $\mathrm{Co}$ and $\mathrm{Ni}$ in the battery electrode of both the $\mathrm{NiMH}$ and Li-ion batteries. All the results for the Co and Ni levels in the battery electrode exceeded the TTLC limits for Co (8000 mg/kg) and $\mathrm{Ni}(2000 \mathrm{mg} / \mathrm{kg})$. In fact, the overall mean Co level of the battery electrode is about 45 times the TTLC limit for Co. Similarly, the overall mean $\mathrm{Ni}$ result is about 38 times the TTLC limit. The $\mathrm{Cr}$ results were generally less than $150 \mathrm{mg} / \mathrm{kg}$ while the Cd levels were less than $20 \mathrm{mg} / \mathrm{kg}$ both being below their corresponding TTLC thresholds. Comparing the mean Co levels of the two battery chemistries with the TTLC limit for Co indicates that the mean values for the Li-ion and NiMH batteries are about 52-times (range 2.6-72 times) and 29-times (range 5-60-times) the TTLC threshold, respectively. On the other hand, the mean Ni levels for the Li-ion and NiMH batteries are in excess of 33-times (range 1.7-123-times) and 48times (range 3-133-times) the TTLC limit for $\mathrm{Ni}$, respectively.

The metal levels obtained in the PWB in most cases were lower than the TTLC limits of the metals analyzed.
Only five results (16\%) exceeded the TTLC limit for Ni. All other results were lower than their corresponding TTLC threshold limits. In fact, the Cr results of the PWB were below $100 \mathrm{mg} / \mathrm{kg}$ while the Cd results were below $10 \mathrm{mg} / \mathrm{kg}$.

The batteries in the estimated 40 million mobile phones in use in Nigeria in 2007 contain approximately 14451 tons of Co and 3011 tons of Ni. These large quantities of valuable materials could be recovered if these batteries are recycled at their end-of-life.

\section{Management practices in Nigeria}

Concern for the environment and the introduction of extended producer responsibility in battery waste management have resulted in the development of 'environment friendlier' batteries and in the sound management of waste batteries in the developed countries. In the absence of 'take-back' programs (either voluntary or mandatory) and effective waste management practices (such as waste separation and recycling), battery wastes present potentials for serious environmental pollution in the developing countries (Nnorom and Osibanjo, 2006b).

Presently, these toxic waste materials are collected with municipal waste and disposed of at open dumps where waste materials are burned to reduce waste volume prior to burial at unlined landfills. Storm runoff could wash these wastes and the resulting ash, as well as cinder and the leachate enter surface water bodies used for domestic purposes. It is also worthy to mention that food crops are also planted very close to such dumpsites and the waste residue used as manure. Gaseous emissions from the open burning activities expose residents and passers-by to large doses of a cocktail of toxins. Studies aimed at assessing the environmental risks posed by the rare earths contained in these batteries; especially in the developing countries that adopt low-end management practices are urgently required.

The implementation of effective system for the collection and disposal or recycling of these batteries in Nigeria will help reduce the dissipation of $\mathrm{Ni}$ and $\mathrm{Co}$ and rare earth metals into the environment. The government should introduce producer responsibility mandating the producers and importers/retailers with the end-of-life management of these waste materials. Alternatively, advance recycling fee (ARF) could be introduced, in which case the users pay for the EoL management of materials while purchasing them. 
Heavy metal content in waste portable recgargable batteries

Table 4: Summary of heavy metal levels in the PWB of mobile phone battery $(\mathrm{mg} / \mathrm{kg}$ )

\begin{tabular}{lrrrr}
\hline Metal & Mean \pm SD & TTLC (Threshold) & N $>$ TTLC & Range \\
\hline Co & $564 \pm 165$ & 8000 & 0 & $56.1-4068$ \\
Cr & $28.1 \pm 4.0$ & 2500 & 0 & ND-97.2 \\
Ni & $735 \pm 188$ & 2000 & 5 & $22.7-2727$ \\
Cd & $1.8 \pm 0.3$ & 100 & 0 & ND-7.2 \\
\hline
\end{tabular}

$\mathrm{N}>\mathrm{TTLC}=$ Number of samples greater than the respective TTLC threshold

Table 5: Comparison of result of Present study with data from literature (x10000 mg/kg)

\begin{tabular}{lrrrr}
\hline Metal & & Literature* $^{*}$ & Present study & NiMH \\
\hline & NiMH & Li-ion & $23.1(4.1-48.2)^{\ddagger}$ & $41.5(2.1-57.5)$ \\
Co & $1.0-4.3$ & $12-20$ & 0.0021 & 0.003 \\
Cr & $0-16$ & $\sim 0$ & 0.0005 & 0.0002 \\
Cd & $\sim 0$ & 0 & $9.6(0.6-26.7)$ & $6.7(0.4-24.6)$ \\
Ni & $25-46$ & $12-15$ & 9.6 & \\
\hline
\end{tabular}

*Data is weighted averages that includes plastics and other packaging materials; Data from Rydh and Svard, 2003. *Data in bracket are range

Table 6: Comparison of metal contents of Li-ion and NiMH battery systems

\begin{tabular}{lrrrr}
\hline Metal & Li-ion Battery $(\mathrm{N}=22)$ & & NiMH Battery $(\mathrm{N}=9)$ & Range \\
& Mean & Range & Mean & Ran \\
$\mathrm{Co}$ & $414618 \pm 31599$ & $20870-575330$ & $230913 \pm 63713$ & $40934-481671$ \\
$\mathrm{Cr}$ & $27.6 \pm 6.0$ & $12.3-149$ & $20.6 \pm 4.9$ & $7.9-54.4$ \\
$\mathrm{Ni}$ & $66880 \pm 16110$ & $3589-245947$ & $96228 \pm 32538$ & $6097-266607$ \\
$\mathrm{Cd}$ & $1.9 \pm 0.4$ & ND-7.9 & $4.8 \pm 1.7$ & $1.4-16.3$ \\
\hline
\end{tabular}

There is also need to appropriately enlighten people on the usage of these materials in order to achieve maximum utilization, their toxicity and sound management practices. For example, most batteries will provide 1000 cycles before the capacity falls below $70 \%$ rated capacity. AGM (2003) observed that users need to be aware that the number of useful cycles will be related to a number of factors including: the rate at which the batteries are discharged, the depth of discharge per cycle, the rate at which the batteries are recharged, the operating temperature and the voltage to which the cells are charged.

\section{Sound management options}

The management of EoL rechargeable batteries is problematic because these devices are complex products in terms of structure and chemical composition. Because some of the material components of these devices are not immediately accessible, each disposal/management option will act in a different way so that the behavior of degradation or transformation is quite different and specific, resulting in different reactions and associated emissions or environmental burdens (Xara et al., 1999). Options available in the management of EoL rechargeable batteries include recycling, incineration and landfilling. Efforts at achieving sustainable development should incorporate environmental management and as well as knowledge management (Huang and Shih, 2009).

The recycling of spent batteries would be the most convenient solution from an environmental point of view. However, Andrade-Tacca and Duarte (2005) observed that there are practical and economic aspects that restrict this option. Options in the recycling of household batteries can be broadly classified as hydrometallurgical and pyrometallurgical based on the main operation in which the process is based. In general, pyrometallurgical processes generate less solid and liquid residue than hydrometallurgical ones. However, the pyrometallurgical processes are energy intensive and generate toxic gaseous emissions (Xara et al., 1999).

Extensive work have been done with the aim of finding the best routes in recycling materials especially rare earth metals and metals such as $\mathrm{Ni}$ and Co from spent NiMH batteries. Most of these studies have been based on hydrometallurgical treatments (Lupi and Pilone, 2002; Tzuanetakis and Scott, 2004; 
Pietrelli et al., 2005). Nickel and Fe could be recovered from used batteries for use in the steel industry. Efficient recovery techniques have been developed for the recovery of spent NiMH batteries (Zhang et al., 1999; Tenorio and Espinosa, 2002). Similarly, LiOH, $\mathrm{Co}, \mathrm{Cu}$ and $\mathrm{Al}$ could be recovered from Li-ion batteries (Lain, 2001; Lee and Rhee, 2002; Rydh and Svard, 2003).

In the absence of recycling facilities, these waste materials could still be collected and incinerated or disposed of in appropriately constructed landfills. The recycling rate for these batteries in Nigeria is zero as there is no form of material recovery currently taking place. The recycling rate at the global level has also not been encouraging. For example, the recycling rate at the global level for 1999 was estimated at 5-50 \% for NiCd and NiMH, and 2-10\% for Li-ion batteries (Rydh and Svard, 2003). Many countries including some developed countries lack effective take-back or collection schemes for spent batteries. This is made difficult by hoarding of batteries, the large number of battery users, and the small size of portable batteries (Rydh and Svard, 2003). In most developing countries, this is compounded by the inadequacies of waste collection receptacles, non-separation of waste at source, and the lackadaisical attitude of the governments and the related enforcement agencies.

\section{CONCLUSION}

This study offers some insight into the metal levels of spent portable rechargeable batteries. The Co and $\mathrm{Ni}$ concentrations of the electrode of $\mathrm{NiMH}$ and Li-ion batteries are so high and far exceeded the TTLC threshold limits used in the toxicity characterization of solid waste, by about 40 -folds the limit concentrations of each of the metals. As a result, spent batteries should be handled as toxic and hazardous wastes. The various low-end management practices for these spent batteries in Nigeria create the potential for a negative impact on the health of the residents, as well as the entire ecosystem. Implementation of a well-coordinated management strategy for spent batteries is urgently required to check the dissipation of large doses of toxic heavy metals and rare earth metals into the environment. Implementation of extended producer responsibility, introduction of an effective collection system and the introduction of environmentally sound material recovery strategy is required in handling this issue. The recovery of spent batteries will in the long- run result in a decrease in the impact on global metal flows arising from the use of portable rechargeable batteries (Rydh and Svard, 2003). The recycling of spent portable rechargeable batteries besides bringing profit in environmental terms can also bring benefits in economic terms.

\section{REFERENCES}

Abdel-Ghani, N. T.; Hefny, M.; El-Chagbaby, G. A. F., (2007). Removal of lead from aqueous solution using low cost abundantly available adsorbents. Int. J. Environ. Sci. Tech., 4 (1), 67-73 (7 pages).

AGM., (2003). Product Manual: Lithium-ion Technology. Adsorbed Glass Mat, AGM Batteries Ltd., November.

Aina, M.; Matejka, G.; Mama, D.; Yao, B.; Moudachirou, M., (2009). Characterization of stabilized waste: Evaluation of pollution risk. Int. J. Environ. Sci. Tech., 6 (1), 159-165 (7 pages).

Aktas, S.; Sirkeci, A.; Acma, E., (2004). Current situation of scrap batteries in Turkey. J. Power Sources, 130 (1-2), 306308 (3 pages).

Andrade-Tacca, C. A.; Duarte, M. M. E., (2005). Acid leaching and electrochemical recovery of manganese from spent alkaline batteries. $2^{\text {nd. }}$ Mercosur Congress on Chemical Engineering, $4^{\text {th. }}$ Mercosur Congress on Process Systems Engineering). EMPROMER, Costa Verde-RJ-Brasil.

Arora, P.; Zhang, Z. J., (2004). Battery separators. Chem. Rev., 104 (10), 4419-4462 (44 pages).

Castillo, S.; Samala, N. K.; Manwaring, K.; Izadi, B.; Radhakrishan, D., (2004). Experimental analysis of batteries under continuous and intermittent operation. In: Proceedings of the International Conference on Embedded Systems and Applications. 18-24 (7 pages).

Daryabeigi Zand, A., Abduli, M. A., (2008). Current situation of used household batteries in Iran and appropriate management policies. Waste Manage., 28 (11), 2085-2090 (6 pages).

DTSC, (2004a). Determination of regulated elements in seven types of discarded consumer electronic products. Hazardous Material Laboratory, California Department of Toxic Substances Control. January. http://www.dtsc.ca.gov/ HazardousWaste/EWaste/upload/Consumer_Electronic_ Products.pdf

DTSC, (2004b). Determination of regulated elements in discarded laptops, LCD monitors, plasma TVs, and LCD TVs. California Department of Toxic Substance Control (Hazardous Material Laboratory). SB20 Report. January. http://www.dtsc.ca.gov/HazardousWaste/EWaste/upload/ HWMP_REP_SB20_LCD.pdf

EPA, (1996). Method 3050B: Acid digestion of sediments, sludges, and soils. SW-846 test methods for evaluating solid wastes. Environment Protection Agency. http:// www.epa.gov/epaoswer/hazwaste/test/main.htm.

Gega, J.; Walkowiak, W., (2001). Hydrometallurgical methods of metal recovery from spent batteries. XVI ${ }^{\text {th. }}$ ARS SEPARATORIA-Browno. Poland, http://dpi.eq.ufrj.br/ CENPROMER2005/nukleo/pdfs/1143 empromer.pdf

Giri, D.; Murthy, V. K.; Adhikary, P. R.; Khanal, S. N., (2007). Estimation of number of deaths associated with exposure to 
excess ambient PM10 air pollution. Int. J. Environ. Sci. Tech., 4 (2), 183-188 (6 pages).

Huang, P. S.; Shih, L. H., (2009). Effective environmental management through environmental knowledge management. Int. J. Environ. Sci. Tech., 6 (1), 35-50 (16 pages).

Lain, M. J., (2001). Recycling of lithium ion cells and batteries., J. Power Sources., 97-98 (1), 736-738 (3 pages).

Lankey, R.; McMicheal, F., (1999). Rechargeable battery management and recycling. A Green Design Education Module. Green Design Initiative Technical Report. Carnegie Mellon University. 1-14.

Lee, C. K.; Rhee, K. I., (2002). Preparation of $\mathrm{LiCO}_{2}$ from spent lithium ion batteries. J. Power Sources., 109 (1), 1721 (5 pages).

Li, Y.; Richardson, J. B.; Walker, A. K.; Youn, P. C., (2006). TCLP heavy metal leaching of personal computer components. J. Environ. Eng., 132 (4), $497-504$ (8 pages).

Lincoln, J. D.; Ogunseitan, O. A.; Shapiro, A. A.; Saphores, J. D. M., (2007). Leaching assessment of hazardous materials in cellular telephones. Environ Sci. Tech., 41 (7), 25722578 (7 pages).

Lu, W.; Chung, D. D. L., (2003). Effect of pitch-based carbon anode on the capacity loss of lithium ion secondary battery., Carbon, 41 (5), 945-950 (6 pages).

Lupi, C.; Pasquali, M.; Dell'Era, A., (2005). Nickel and cobalt recycling from lithium-ion batteries by electrochemical processes. Waste Manage., 25 (2), 215-220 (6 pages).

Lupi, C.; Pilone, D., (2002). Ni-MH spent batteries: A raw material to produce Ni-Co alloys. Waste Manage., 22 (8), 871-874 (4 pages).

Moshtev, R.; Johnson, B., (2000). State of the art of commercial Li-ion batteries. J. Power Sourc., 91 (2), 86-91 (5 pages).

Nnorom, I. C.; Osibanjo, O., (2006a). Determination of lead and cadmium contents of dry cell batteries available in Nigeria. J. Appl. Sci. Environ. Manage., 10 (3), 37-41 (5 pages).

Nnorom, I. C.; Osibanjo, O., (2006b). Estimation of consumption emissions of lead and cadmium from dry cell battery importation in Nigeria: (1980-1998). J. Appl. Sci., 6 (7), 1499-1505 (7 pages).

Nnorom I. C.; Osibanjo, O., (2008). Toxicity characterization of waste mobile phone plastics. J. Hazard Mater., 161 (1), 183-188 (6 pages).

Ogundiran, O. O.; Afolabi, T. A., (2008). Assessment of the physicochemical parameters and heavy metals toxicity of leachates from municipal solid waste open dumpsite. Int. J. Environ. Sci. Tech., 5 (2), 243-250 (8 pages).

Osibanjo, O.; Eyanohonre, A. E.; Nnorom, I. C., (2008). Heavy metals in alkaline and zinc-carbon dry cells as pollution indicators of spent batteries. Eur. J. Sci. Res., 20 (3), 593603 (11 pages)

Pietrelli, L.; Bellomo, B.; Fontana, D.; Montereali, M., (2005). Characterization and leaching of NiCd and NiMH spent batteries for recovery of metals. Waste Manage., 25 (2), 221-226 (6 pages)

Rabah, M. A.; Farghaly, F. E.; Abd-El Motaleb, M. A., (2008). Recovery of nickel, cobalt and some salts from spent NiMH batteries. Waste Manage., 28 (7), 1159-1167 (9 pages).

Rydh, C. J.; Svard, B., (2003). Impact on global metal flows arising from the use of portable rechargeable batteries. Sci. Total Environ., 302 (1-3), 167-184 (18 pages).

Saito, T.; Sato, H.; Motegi, T., (2003). Extraction of rare earth from La-Ni alloys by the glass slag method. J. Mater. Res., 18 (12), 2814-2819 (6 pages).

Tenorio, J. A. S.; Espinosa, D. C. R., (2002). Recovery of Nibased alloys from spent NiMH batteries. J. Power Sources, 108 (1-2), 70-73 (4 pages).

Townsend, T. G.; Jang, Y. C.; Tolaymat, T.; Jambeck, J., (2001). Draft annual report. Leaching tests for evaluating risk in solid waste management decision making: Year I. Florida Center for Solid and Hazardous Waste Management. University of Florida, Gainesville, Fla. http://www.ees.ufl.edu/ homepp/townsend/Research/Leach/Leach_Yr1.pdf.

Tzuanetakis, N.; Scott, K., (2004). Recycling of nickel-metal hydride batteries, I: Dissolution and solvent extraction of metals., J. Chem. Tech. Biotech., 79 (9), 919-926 (8 pages).

Xara, S.; Silva, M.; Almeida, M. F.; Costa, C., (1999). Life cycle analysis and solid waste management: Household batteries. In: Proceedings Sardinia 99, Seventh International Waste Management and Landfill Symposium. S. Margherita di Pula, Cagliari, Italy. 4-8 October, CISA Environmental Sanitary Engineering.

Zabaniotou, A.; Kouskoumvekaki, E.; Sanopoulos, D., (1999). Recycling of spent lead/acid batteries: The case of Greece. Resour. Conserv. Recy., 25 (3-4) 301-317 (17 pages).

Zhang, P.; Yokoyama, T.; Itabashi, O.; Wakui, Y.; Suzuki, T.M.; Inoue, K., (1999). Recovery of metal values from spent nickel-metal hydride rechargeable batteries. J. Power Sources., 77 (2), 116-122 (7 pages).

\section{AUTHOR (S) BIOSKETCHES}

Nnorom I. C., M.Sc., Lecturer, Department of Industrial Chemistry, Abia State University, Nigeria and Ph.D. research student in Analytical/ Environmental Chemistry, University of Ibadan, Nigeria. Email: chidiabsu@yahoo.co.uk

Osibanjo O., Ph.D., Professor, Executive Director of Basel Conventional Regional Coordinating, Centre for Africa on Hazardous Waste Management and Lecturer, Department of Chemistry, University of Ibadan. Email: oosibanjo@baselnigeria.org

How to cite this article: (Harvard style)

Nnorom I. C.; Osibanjo O., (2009). Heavy metal characterization of waste portable rechargeable batteries used in mobile phones. Int. J. Environ. Sci. Tech., 6 (4), 641-650. 